(RESEARCH ARTICLE)

\title{
In vitro anti-urolithic activity of Chandraprabavathi - A herbo-mineral formulation
}

\author{
Vimalavathini $\mathrm{R}^{*}$, M Arthi, M Arunkumar and Gnanavelou D \\ College of Pharmacy, MTPG \& RIHS, Pondicherry 605 006, India.
}

Publication history: Received on 21 September 2019; revised on 17 October 2019; accepted on 22 October 2019

Article DOI: https://doi.org/10.30574/wjarr.2019.3.3.0067

\begin{abstract}
Chandraprbhavati (CPV) is an Ayurvedic formulation clinically used in the management of urinary calculi. The present study was undertaken to investigate the in-vitro antiurolithic activity of CPV by artificial urine and nucleation assay. Cystone demonstrated better percentage inhibition of calcium oxalate crystals formation than CPV in nucleation assay, however CPV exhibited more inhibition of super saturation of calcium oxalate crystals in artificial urine assay than cystone. The percentage inhibition of calcium oxalate crystals formation increased in dose dependent manner for both the drugs. Thus our study demonstrates primary evidence for CPV possessing antiurolithiatic property in vitro.
\end{abstract}

Keywords: Chandraprabhavati; Anti-urolithic; Renal stones

\section{Introduction}

Urolithiasis is formation of urinary calculi at any level of urinary tract. The treatment of urolithiasis is involves the dissolution of existing stones and preventing the reoccurrence of stones. An alarming rise in the incidence and recurrence of urolithiasis coupled with adverse effects allopathic drugs necessitates exploration of traditional mode of treatment. [1] Chandraprabha vati (CPV) is an Ayurvedic formulation available in vati form and is clinically used in the management of urinary calculi. Though being clinically used in Ayurveda still no scientific evidence for antiurolithic activity of CPV has been established. The present study was undertaken to investigate the in-vitro antiurolithic activity of CPV by artificial urine assay and nucleation assay.

\section{Material and methods}

\subsection{Chemicals}

Cystone was procured from Himalaya Drug Company, Karnataka, India and CPV from Kottakkal Arya Vaidyasala, Kerala. Calcium chloride, sodium oxalate, Tris buffer, sodium chloride, sodium phosphate, sodium citrate, magnesium sulphate, sodium sulphate, potassium chloride, ammonium hydroxide, ammonium chloride, sulphuric acid, ammonia, hydrochloric acid, potassium permanganate were procured from Merck Specialities Private Limited, Mumbai.

\subsection{Apparatus}

UV Spectrophotometer- Thermos Fisher Scientific, UK

\subsection{Nucleation assay}

Solution of calcium chloride and sodium oxalate at concentrations of $5 \mathrm{mmol} / \mathrm{L}$ and $7.5 \mathrm{mmol} / \mathrm{L}$ respectively was prepared in a buffer containing Tris $0.05 \mathrm{mmol} / \mathrm{L}$ and $\mathrm{NaCl} 0.15 \mathrm{~mol} / \mathrm{L}$ at $\mathrm{pH} 6.5 .950 \mu \mathrm{l}$ of calcium chloride solution was mixed with of test drug and standard (cystone) at different concentrations. Crystallization was started by adding

\footnotetext{
* Corresponding author

E-mail address: vimalavathini@gmail.com
} 
$950 \mu \mathrm{l}$ of sodium oxalate and incubated for $30 \mathrm{~min}$ at $37^{\circ} \mathrm{C}$ and optical density of the solution was measured at 620 $\mathrm{nm}$. The percentage inhibition of calcium oxalate crystal formation was calculated. [2]

\subsection{Artificial urine (AU) assay}

The artificial urine was prepared according to the method Burns and Finlayson,it consist of sodium chloride 105.5 $\mathrm{mM}$, sodium phosphate $32.3 \mathrm{mM}$, sodium citrate $3.21 \mathrm{mM}$, magnesium sulfate $3.85 \mathrm{mM}$, sodium sulfate $16.95 \mathrm{mM}$, potassium chloride $63.7 \mathrm{mM}$, calcium chloride $4.5 \mathrm{mM}$, sodium oxalate $0.32 \mathrm{mM}$, ammonium hydroxide $17.9 \mathrm{mM}$, and ammonium chloride $0.0028 \mathrm{mM}$. The AU was prepared fresh each time and $\mathrm{pH}$ adjusted to 6.0. $1.0 \mathrm{ml}$ of AU was added to $0.5 \mathrm{ml}$ of distilled water and blank reading was taken. The $0.5 \mathrm{ml}$ of $0.01 \mathrm{M}$ sodium oxalate was added and the measurement is immediately started for a period of ten minutes. The standard and test substance were prepared in different concentration. A mixture of $1 \mathrm{ml}$ of $\mathrm{AU}$ and $0.5 \mathrm{ml}$ of test solution was taken as blank reading and then $0.5 \mathrm{ml}$ of $0.01 \mathrm{M}$ sodium oxalate solution was added and immediately the absorbance was measured for a period of ten minutes at $620 \mathrm{~nm}$. The percentage of inhibition of calcium oxalate crystal formation was calculated. [3] All results are represented as mean $\pm \mathrm{SEM}$.

\section{Results and discussion}

Cystone exhibited better percentage inhibition than CPV (Fig 1) in nucleation assay and percentage inhibition increased in dose dependent manner for both the drugs. But CPV has more percentage inhibition of super saturation of calcium oxalate crystals (Fig 2) in artificial urine assay than cystone and percentage inhibition increased in dose dependent manner for both the drugs. Thus our study demonstrates that CPV exhibits good anti-urolithic activity comparable to that of the standard, cystone.

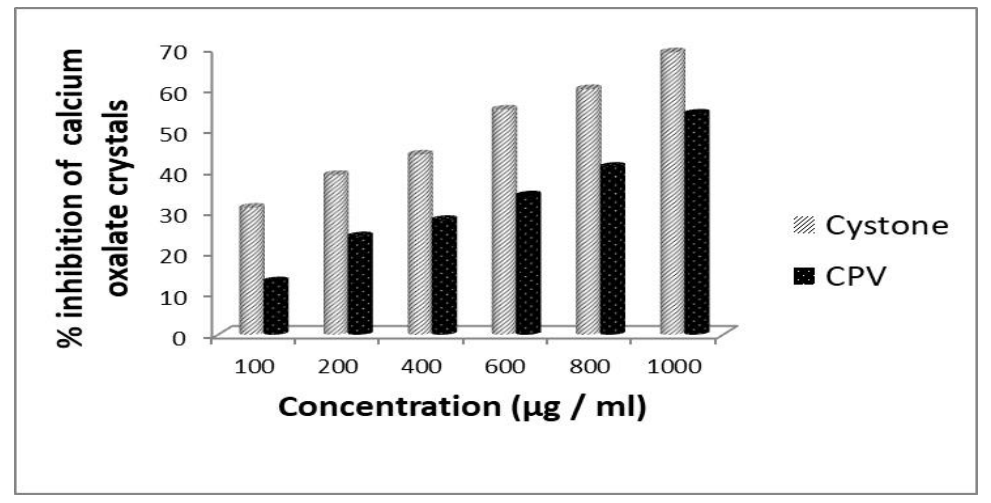

Figure 1 Effect of CPV and cystone on calcium oxalate crystallisation for nucleation assay

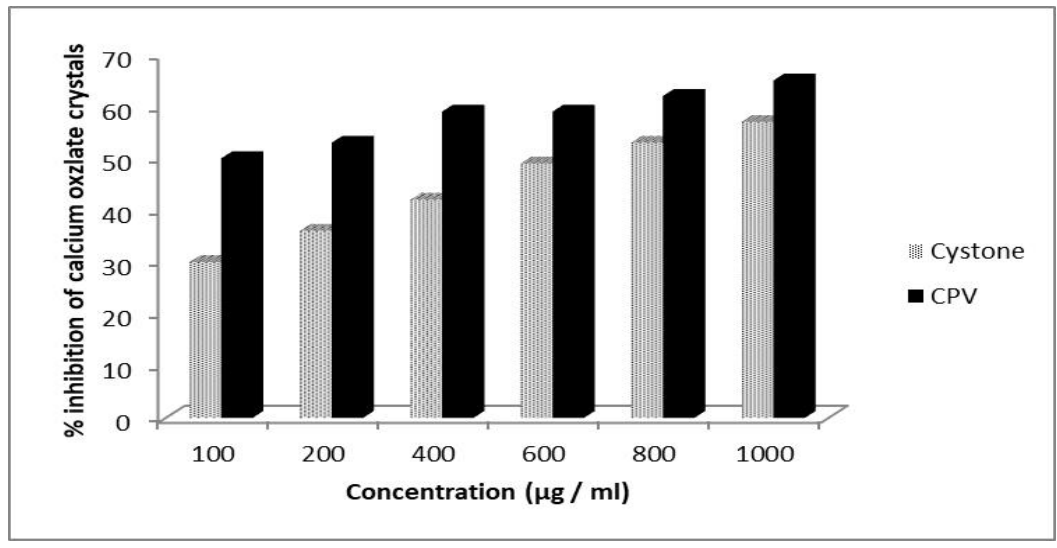

Figure 2 Effect of CPV and cystone on calcium oxalate crystallisation for artificial urine assay

CPV has phytoconstituents such as alkaloids, flavonoids, carbohydrates, sterols and triterpenoids, tanins and phenolic compounds.[4] Tannin might have contributed to the inhibition of calcium oxalate crystals formation.[5] Terpenoids has shown to inhibit the cytotoxicity induced by calcium oxalate, they are also know to normalize excretion of stone forming constituents.[6] Flavonoids possess urolithic dissolution potency and antioxidant activity. ${ }^{[5]}$ Phenolic 
constituents exhibit antioxidant activity and prevent crystal adhesion and subsequent formation of urinary stones.[7] Therefore anti-urolithic activity of CPV would have been an outcome of these phytoconstituents present in CPV.

\section{Conclusion}

This study has given primary evidence for CPV possessing antiurolithiatic property in vitro. However, further study in animal models of urolithiasis is needed to evaluate its potential antiurolithiatic activity.

\section{Compliance with ethical standards}

\section{Disclosure of conflict of interest}

No conflict of interest

\section{References}

[1] Chakradhar KV. (2012). A Comparative Clinical study on Renal calculi- An Ayurvedic Perspective. Journal of Dental and Medical Sciences, 5(2), 21-32.

[2] Sasikala V, Radha SR and Vijayakumari B. (2013). In-Vitro evaluation of Rotula aquatica Lour. for antiurolithiatic activity. Journal of Pharmacy Research, 6, 378-382.

[3] Srinivasa AKB, Kuruba L, Khan S and Saran GS. (2013). Antiurolithiatic activity of Gokhsuradi Churan, an Ayurvedic Formulation by In-Vitro Method. Advanced Pharmaceutical Bulletin, 3(2), 477-479.

[4] Weerasekera KR, Wijayasiriwardhena C, Dhammarathana I, Tissera MH, Ariyawansha HA. (2014). Establishment quality and purity of "Chandraprabha vati" using sensory characteristics, physiochemical parameters, qualitative screening and TLC fingerprinting. Int J Herb Med, 2, 26-29.

[5] MHA and Ariyawansha HAS. (2014). Establishment quality and purity of Chandraprabha vati using sensory characteristics, physiochemical parameters, qualitative screening and TLC Fingerprinting. International Journal of Herbal Medicine, 2 (3), 26-29.

[6] Bawari S, Sah AN and Tewari D. (2018). Antiurolithiatic activity of Daucus carota: An in vitro study. Pharmacognosy journal, 10(5), 880-884.

[7] Barros ME, Lima R, Mercuri LP, Matos JR, Schor N and Boim MA. (2006). Effect of extract of Phyllanthus niruri on crystal deposition in experimental urolithiasis. Urological Research, 1-8.

[8] Mandal B, Mandan S and Ahmad S. (2013). In vitro inhibition of calcium oxalate nucleation by extract-based fractions of aerial parts and roots of Aerva lanata (Linn.) Juss. ex Schult. Indian Journal of Pharmaceutical Sciences, 79(6), 957-964.

\section{How to cite this article}

Vimalavathini R, M Arthi, M Arunkumar and Gnanavelou D. (2019). In vitro anti-urolithic activity of Chandraprabavathi - A herbo-mineral formulation. World Journal of Advanced Research and Reviews, 3(3), 38-40. 